\title{
Rhetorical Agency in the Face of Uncertainty
}

\section{Articulating, Negotiating, and Leveraging Risk}

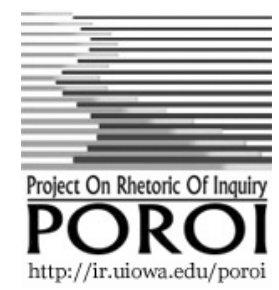

Lora Arduser

University of Cincinnati

Cincinnati, $\mathrm{OH}$

\section{Lucia Dura}

The University of Texas at El Paso

El Paso, TX

\section{Jennifer Malkouski}

Wake Forest University

Winston-Salem, $\mathrm{NC}$

Poroi 11,1 (May 2015)

Living with global terrorism, global epidemics, and new medical technologies has made risk a dominant theme in the 21st century in terms of both individual action and public policy. This condition has led us to become more occupied with debating, preventing, and managing risks. -Ulrich Beck, World Risk Society, 1996

Any time we read or watch the news, the global, scientifically saturated nature of the world becomes apparent. Current events pertaining to medical risks in particular have become increasingly significant. Take, for example, the recent Ebola situation in which we have witnessed how infectious disease threat and communication of risk ignite and stoke public frenzy about how to act and whom to blame. Think of the news coverage on whether the "infected Dallas nurse" did or did not follow "protocol" leaving her and other innocent bystanders vulnerable to contracting Ebola. Also consider the treatment of the nurse in Maine who defied politically issued-not medically issued-“quarantine orders" and went for a bike ride.

Perceptions of harm get encased in public talk where "worst case scenario" storylines not only dominate and direct discussion but also lead to action. In this regard, and in response to her quarantine orders specifically, the "Maine nurse," Kaci Hickox, 
argued that the U.S. would be better served by "evidence-based policies," not "knee-jerk reactions" fueled by fear (Worland, 2014). As a society, we work hard to "anticipate and control [risks] (rhetorically and otherwise)" (Scott, 2012, 30). We do this even though risk is always about possibility and, therefore, is an unpredictable, uncontrollable combination of cultural perceptions, rhetorical constructions, and material effects (Beck, 1999; see also Douglas and Wildavsky, 1982; Kasperson and Kasperson, 2005; Scott, 2012).

Despite its slippery ambiguity, we propose that risk must be managed in ways that account for these cultural perceptions, rhetorical constructions, and their impact on stakeholders. The presentations in this panel focused on three interrelated roles of rhetoric in shaping and managing medical risk: articulation, negotiation, and leveraging. We argued that viewing Beck's theory of reflexive modernization through a rhetorical lens, particularly in terms of agency, highlights his idea that modernization involves "a changing relationship between social structures and social agents" (Beck, 1992, 2).

To unpack the rhetorical dynamics that regulate how we understand and act on risk (Dean 2000), we raised the following questions: How can medical risks and risk-management practices impact individual, social, and institutional identities? What roles do risks play in the generation, dis-assembling, and re-articulation of medical arguments, understandings, and relations? How can medical risks-as dynamic rhetorical constructions with material impacts-diffuse, destabilize, and otherwise complicate rhetorical agency?

\section{BIOANXIETY AND RISK MANAGEMENT}

In her presentation "Leveraging Risk and Advancing a Theory of Biotechnological Anxiety for Medicine's Future," Jennifer Malkowski characterized medical risks as taking place in an era of rapidly spreading and mutating viruses. Drawing from a Foucauldian-informed line of biosecurity studies, bioinsecurity studies, studies of biocitizenship, and theories of biomedicalization, Malkowski framed her argument around a concern she calls "bioanxiety" (Rosa and Novas, 2005; Rose, 2007; Lakoff and Collier 2008; Klotz and Sylvester, 2009; Clarke et al., 2010; Keränen, 2011). In her lexicon, bioanxiety refers to excessive worry about everyday living that is generated by the large, nebulous problems affiliated with biotechnological advancement, such as those related 
to vaccination. Bioanxiety, Malkowski suggests, contributes to health experiences whereby members of various audiences are left with more questions than answers (e.g. "So now I know that I have multiple sclerosis, but the doctors don't really know what causes or cures it or even what to expect in terms of how it will affect me personally?"), more concern than catharsis (e.g. "So now I know about bioterrorism, but what can I really do to protect myself?") and, indelibly, evermore anxious about future health decisions (e.g. "If I decide to undergo genetic testing and find out I have "the breast cancer gene' what action should I take next and what if that action poses immediate risks?”).

Malkowski drew from political and professional communication concerning mandatory health care worker influenza vaccinations at both national and state levels and from evidence of the public backlash the issue has generated. Using these discourses, she illustrated how emotion, specifically anxiety, now animates much public discussion about risk response technologies, including vaccination. Her argument was that bioanxiety can be understood to describe the condition in which we (are made to) live. Convinced that vaccination talk impacts the material conditions of medical intervention and also social, political, and cultural realities, Malkowski noted that vaccination is a charged issue quite independent of the efficacy of any particular vaccine; both imminent and imagined disease threat inspire similar sorts of vaccination talk. Regardless of specific disease threats or intervention technology, concerns about vaccination-associated risks tend to assume a recognizable pattern: Expressions of concern about how vaccination infringes on human rights exposes financial incentive and inequities in health-care and troubles medicine's relationship with nature. This pattern, according to Malkowski, foregrounds both the materiality and recalcitrant nature of biomedical intervention and the symbolic force of communication about such conditions. Currently that symbolic potential seems to be inspiring anxiety at the individual level, making one wonder if it may be inspiring anxiety at the collective level as well. In theorizing beyond the limits of the particular case of vaccination anxiety, Malkowski suggests that bioanxiety, as both a risk communication characteristic and consequence, may be leveraged in ways that turn attention back to common realties associated with risky living, a perspective that could mend troubled relationships between medicine and its publics.

As Malkowski's work illustrates, the relationship between medicine and its publics, which is characterized by an increase in disease threat awareness and a decrease in public trust in medicine, 
creates tension for contemporary risk management practices. The pairing of threat and distrust breeds concern about the status of medicine more broadly and the nature of health care practices specifically, which causes unique problems for public health initiatives predicated on collective action. In this regard, recognition of bioanxiety as a common consequence of public deliberation about medical risk (rather than as an accurate reflection of the status of any particular disease risk or intervention efficacy) could foreground the collective, rhetorical agency available to us in all matters of preventative medicine, with vaccination serving as but one example. If we diagnose ourselves as suffering from a similar condition whose root cause is communicative in nature, we might mobilize that commonality and "suffering" to insist on changing how risk and responses to risk are discussed across contemporary settings. Such an outcome could influence the success of vital risk interventions.

\section{LIMINALITY IN DIABETES SELF-MANAGEMENT}

In "Negotiating Risk and Agency in Public Spaces of Chronic Care," Lora Arduser argued that people with chronic illnesses present a microcosm from which we can examine the broader issue of living in a society of perpetual unpredictability and permanent liminality. A liminal situation, Agnes Horvath explains, is "any situation where borderlines and boundaries that previously were stable and taken for granted are dissolved" and "events happen that are never ending" (Horvath 2013, 10, 3). In the context of managing chronic and complex diseases, decision-making about risks has been characterized as embedded in uncertainty as well. Patients have to balance "a present known quality of life and an uncertain one in the future" (Barre, Beauchemain, Bocti, Broadbent, and Cohen, 2015, $51)$.

In her presentation, Arduser pointed to the case of people with diabetes as existing in a permanent state of liminality. These individuals live with the anticipations of material risks. Their blood sugar may go too low. If so, they risk losing consciousness or going into seizures. At the same time, they are constantly bombarded with messages about the dangers of letting their blood sugar levels remain too high because these high numbers can lead to long-term risks of heart failure, blindness, kidney damage, and amputations. At the same time, the disease and the actions associated with managing (or mis-managing) diabetes invite symbolic risks that involve issues of identity and agency. Diabetics, particularly people 
with type 2 diabetes, run the risk of being seen as uncontrolled, noncompliant, and lacking will power.

Faced with material and symbolic risks, people with diabetes negotiate agency within a network of relationships in which they shift their orientations to their own bodies, other individuals, discourses, and knowledge. One example Arduser gave of this renegotiation of identity occurred during one of the focus groups she conducted with diabetics for her project. Over the course of discussion in this group, the participant who had been diabetic the longest established a "pack leader" identity. He responded first to each question, as others in the focus group seemed to defer to his expertise by readily giving him the floor. Yet, as he talked about his role in mentoring people in a diabetes online community, the same participant downplayed his expertise as a patient in his insistence of the importance of listening to the advice of medical professionals.

Rhetorical agency as negotiation, Arduser argued, occurs in liminal spaces because in these spaces assumptions about power and authority can be challenged, including assumptions about patient expert identities and the narrative in which these identities perform. Such spaces encourage counter narratives about risk, the identity of "patient expert," and the development and enactment of these counter narratives are an expression of rhetorical agency. In other words, the liminal and temporary nature of rhetorical agency in public spaces of chronic illness provides ways to negotiate physical and symbolic risks by enacting agency, questioning, challenging, reinterpreting, and renegotiating both discursive and material elements in these spaces.

\section{WHAT WORKS IN HIGH RISK SITUATIONS}

Lucia Dura gave another reading of the relational nature of risk, subjectivity, and agency in "What Works? What is Possible? Positive Deviance as a Rhetorical Flip in Risk Communication.” Dura looked at subjectivities in risk situations drawing on a case study focused specifically on health care associated infections (HAI). She asked, "Who are we in this risk situation?" Some options she suggested were 'vectors of infection,' 'infected or diseased,' 'in danger,' 'vulnerable,' and 'dangerous.' Based on these subjectivities in the context of HAI, risk is usually addressed by technical directives such as instructions for proper hand washing, punitive action for non-compliance, or pharmaceutical intervention. Dura postulated that because of our tendency to focus on the problem and barriers to success, existing positive outcomes and successful behaviors are often ignored. She proposed a 
rhetorical shift in the face of intractable issues, such as HAIs, through the positive deviance approach: What is working when it shouldn't be working?

Positive deviance questions normative ways of thinking, particularly the "norm" in the bell curve. Nassim Nicholas Taleb, in writing about the pitfalls of relying too heavily on the bell curve in social spheres, argued that the bell curve glorifies mediocrity, disregarding the promise lurking in large deviations and outliers (Taleb, 2007). The positive deviance approach enables the identification of outliers as a starting point. Then, Dura explained, through rhetorical action positive deviance facilitates the discovery of outliers' successful, replicable, and uncommon behaviors and practices. Positive deviants "lurk" at all organizational levels, e.g., frontline health providers, cleaning staff, and even patients and their families. The discovery of solutions to intractable problems, such as HAI in healthcare settings, by individuals "just like me" is empowering not just for outliers themselves, but also for their peers. Such emphasis on local assets brings with it peer-to-peer learning, local ownership of solutions, and a focus on relationships-in essence, culture change.

Dura argued that positive deviance offers rhetoric and communication scholars a new lens through which to view the articulation of risk and to facilitate agency. By focusing on bright spots in risk situations, Dura explained, we leverage assets and create spaces for the construction of new positive narratives that affect individual and collective identities in risk situations. Scholars and practitioners can use positive deviance as an inventional framework for research or as a performative interventional strategy for social and organizational change. The methodology has been applied to risk in a variety of contexts, e.g., education (persistence and graduation); exploitation of vulnerable populations (trafficking and reintegration of child soldiers); public health (selfmanagement, disease prevention, female genital cutting); and mental health (resilience). Still, positive deviance is not a "magic bullet." Dura discussed several challenges: Positive deviance requires an investment of time and social capital, necessitates belief in the value of local expertise, and can be challenging to present to scientists and technical experts because of its relational nature. Nonetheless, in concordance with her fellow panelists, Dura highlighted the potential of rhetorical concepts for acting heuristically to aid various publics in imagining otherwise when it comes to matters of risk and such communication. 


\section{CONCLUSION}

This panel highlighted the pressing need for rhetoricians of science and medicine to address complexity, uncertainty, and ambiguity as they relate to contemporary risk responses. We approached this challenge by (1) recognizing that cultural perceptions and rhetorical constructions of risk derive their power more from anticipation than from actualization; (2) critically examining the functions of dominant risk constructions; and (3) proposing alternative constructions, particularly with agency ${ }^{1}$ in mind. We discussed risk situations in contemporary health and medicine as existing in a biological state of vague apprehension, a permanent liminal state of threat and uncertainty, and as an alternative accessible approach when a 'normal' way of doing things needs to make way for a 'new normal' in order to enact positive social change. These alternative frames, we argue, produce conditions whereby greater trust and fluency concerning risk communication enables the most vulnerable to live with a fuller degree of agency.

\section{REFERENCE LIST}

Allen, D., V. Badro, L. Denyer-Willis, M. E. Macdonald, A. Pare, T. Hutchinson, P. Barre, R. Beauchemain, H. Bocti, A. Broadbent, and S. R. Cohen. "Fragmented Care and WholePerson Illness: Decision-Making for People with Chronic End-Stage Kidney Disease." Chronic Illness 11 (2015): 44-55.

Beck, U. World Risk Society. Cambridge, UK: Polity Press, 1999.

------ "Living in the World Risk Society." Economy and Society 35 (2006): 329-345.

Clarke, A. E., J. K. Sim, L. Mamo, J. R. Fosket, and J. R. Fishman. "Biomedicalization: Technoscientific Transformations of Health, Illness, and U.S. Biomedicine.” American Sociological Review 68 (2003): 161-191.

Dean, M. "Risk, Calculable and Uncalculable.” In D. Lupton (Ed.) Risk and Sociocultural Theory: New Directions and Perspectives. (Pp. 131-159). Cambridge, UK: Cambridge University Press, 2000.

${ }^{1}$ We align with scholarship that recognizes that agency emerges from "the conjunction of a set of social and subjective relations that constitute the possibility of action" (Herndl and Licona, 2007, 133). 
Douglas, M. and A. Wildavsky. Risk and Culture. Los Angeles: University of California Press, 1982.

Herndl, C. G., and A. C. Licona. "Shifting Agency: Agency, Kairos, and the Possibilities of Social Action." In Zachary, M. and C. Thralls (Eds.) Communicative Practices in Workplaces and the Professions: Cultural Perspectives on the Regulation of Discourse and Organizations. (Pp. 133-153). Amityville, NY: Baywood, 2007.

Horvath, A. Modernism and Charisma. New York: Palgrave Macmillan, 2013.

Kasperson, J. and R. Kasperson. The Social Contours of Risk. Volume I: Publics, Risk Communication and the Social Amplification of Risk. London: Earthscan, 2005.

Kera $\square$ nen, L. "Concocting Viral Apocalypse: Catastrophic Risk and the Production of Bio(in)security." Western Journal of Communication 75 (2011): 1-22.

Klotz, L. C. and E. J. Sylvester. Breeding Bio Insecurity: How U.S. Biodefense is Exploiting Fear, Globalizing Risk, and Making Us All Less Safe. Chicago: University of Chicago Press, 2009.

Lakoff, A. and S. J. Collier (Eds.) Biosecurity Interventions: Global Health and Security in Question. New York: Columbia University Press, 2008.

Rose, N. The Politics of Life Itself: Biomedicine, Power, and Subjectivity in the Twenty-First Century. Princeton: Princeton University Press, 2007.

Rose, N. and C. Novas. "Biological Citizenship.” In Ong, A. and S. J. Collier (Eds.) Global Assemblages: Technology, Politics, and Ethics as Anthropological Problems. (Pp. 440-463). Oxford: Blackwell Publishing, 2005.

Scott, J.B. "Tracking the "Transglocal" Risks in Pharmaceutical Development: Novartis's Challenge of Indian Patent Law.” In Dingo, R. and J.B. Scott (Eds.) The Megarhetorics of Global Development. (Pp. 29-53). Pittsburgh: University of Pittsburgh Press, 2012.

Taleb, N. The Black Swan. New York: Random House, 2007.

Worland, J. "Nurse Explains Why She Fought Quarantine." TIME. (2014, November): http://time.com/3556032/ebola-nursekaci-hickox-quarantine/ Accessed 11/5/14. 